\title{
Polyketides from a Marine-Derived Fungus Xylariaceae sp.
}

\section{Xu-Hua Nong ${ }^{1,2}$, Zhi-Hui Zheng ${ }^{3}$, Xiao-Yong Zhang ${ }^{1}$, Xin-Hua Lu ${ }^{3}$ and Shu-Hua Qi ${ }^{1, *}$}

1 Key Laboratory of Marine Bio-Resources Sustainable Utilization, Guangdong Key Laboratory of Marine Materia Medica, RNAM Center for Marine Microbiology, South China Sea Institute of Oceanology, Chinese Academy of Sciences, 164 West Xingang Road, Guangzhou 510301, Guangdong, China; E-Mails: nongxuhua4883@163.com (X.-H.N.); zhangxiaoyong@scsio.ac.cn (X.-Y.Z.)

2 University of Chinese Academy of Sciences, Beijing 100049, China

3 New Drug Research \& Development Center of North China Pharmaceutical Group Corporation, Shijiazhuang, Hebei 052260, China; E-Mails: z_zhihui2003@yahoo.com.cn (Z.-H.Z.); luxinhua@ncpcrd.com.cn (X.-H.L.)

* Author to whom correspondence should be addressed; E-Mail: shuhuaqi@scsio.ac.cn; Tel.: +86-20-8902-2112; Fax: +86-20-8445-8964.

Received: 19 March 2013; in revised form: 22 April 2013 / Accepted: 25 April 2013 / Published: 21 May 2013

\begin{abstract}
Eighteen polyketides (1-18) including six citrinin derivatives, two phenol derivatives, one cyclopentenone, two naphthol derivatives, and seven tetralone derivatives were isolated from the culture broth of a marine-derived fungal strain Xylariaceae sp. SCSGAF0086. Five of these compounds $(\mathbf{1}, \mathbf{2}, \mathbf{8}, \mathbf{9}$, and 10) were new, and their structures were determined by spectroscopic methods. Compounds 4, 6, 7, and 17 showed enzyme-inhibitory activities towards several tested enzymes, and $\mathbf{6}$ and $\mathbf{7}$ showed strong antifouling activity against Bugula neritina larvae settlement. This is the first time that the antifouling and enzyme-inhibitory activities of these compounds has been reported.
\end{abstract}

Keywords: Xylariaceae sp.; polyketide; enzyme-inhibitory activity; antifouling activity

\section{Introduction}

Gorgonian surfaces are frequently colonized by diverse fungi. These symbiotic fungi are becoming new sources of various bioactive compounds [1-5]. During the course of our investigation on secondary metabolites of marine gorgonian-derived fungi, the fungal strain Xylariaceae sp. SCSGAF0086 
attracted our attention. Preliminary experiment showed that the culture extract of the strain had antifouling and antibacterial activities. Further investigation on the chemical constituents of the extract led to the obtainment of 18 polyketides (1-18) (Figure 1) from Xylariaceae sp. SCSGAF0086. These polyketides included six citrinin derivatives, two phenol derivatives, one cyclopentenone, two naphthol derivatives, and seven tetralone derivatives, which displayed the diversity of secondary metabolites of the marine-derived fungal strain. Five of these compounds $(\mathbf{1}, \mathbf{2}, \mathbf{8}, \mathbf{9}$, and 10) were new, and the other compounds were identified as 1-acetonyl-7-carboxyl-6,8-dihydroxy-3,4,5-trimethylisochroman (3) [6], dihydrocitrinone (4) [7], stoloniferol B (5) [7], dicitrinin A (Wakana named it penicitrinone A, 6) [8,9], phenol A acid (7) [9], 8-methoxy-1-naphthyl $\beta$-glucopyranoside (11) [10], ( \pm )-scytalone (12) [11], (4R)-(-)-5-O-methylsclerone (13) [12], (4R)-(-)-4,8-dihydroxy-1-tetralone (14) [13,14], (4R)-(-)-regiolone (15) [15], (4R)-(-)-5-hydroxy-4-methoxy-1-tetralone (16) [16], (3R,4S)-(+)-4-hydroxy-6-deoxyscytalone (17) [17], and $(3 S, 4 R)-(+)-3,4,5$-trihydroxy-1-tetralone (18) [18].

Figure 1. Structures of compounds 1-18.
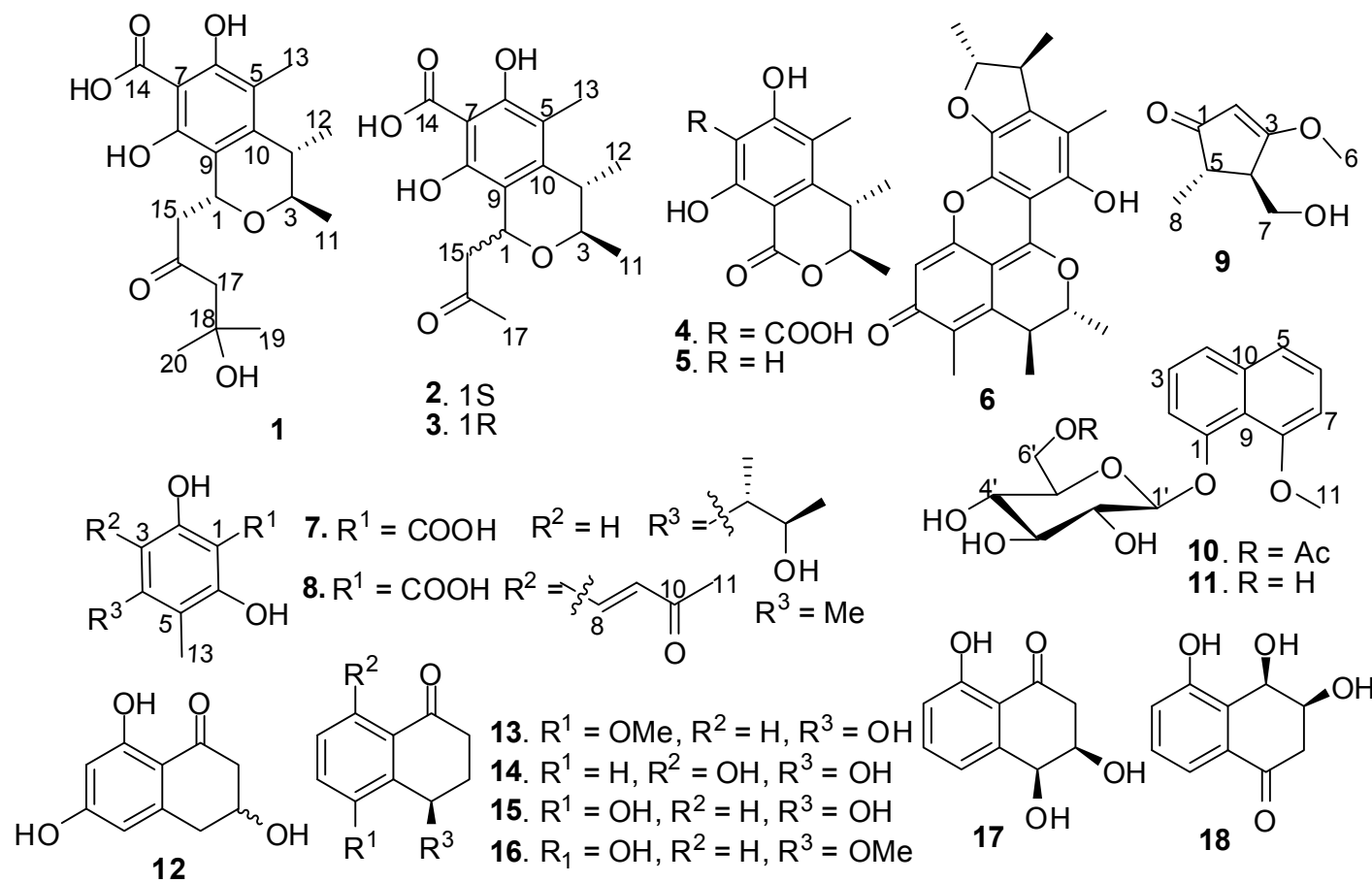

13. $\mathrm{R}^{1}=\mathrm{OMe}, \mathrm{R}^{2}=\mathrm{H}, \mathrm{R}^{3}=\mathrm{OH}$ 14. $\mathrm{R}^{1}=\mathrm{H}, \mathrm{R}^{2}=\mathrm{OH}, \mathrm{R}^{3}=\mathrm{OH}$ 15. $\mathrm{R}^{1}=\mathrm{OH}, \mathrm{R}^{2}=\mathrm{H}, \mathrm{R}^{3}=\mathrm{OH}$ 16. $R_{1}=O H, R^{2}=H, R^{3}=O M e$

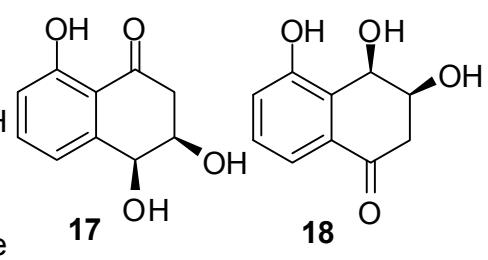

Compounds 1-18 were tested for enzyme-inhibitory activities towards cathepsin B, inosine monophosphate dehydrogenase (IMPDH), protein tyrosine phosphatase 1B (PTPIB), and Src homology 2 domain-containing phosphotyrosine phosphatase (SHP2), and antifouling activity toward Bugula neritina larvae settlement. This paper describes the isolation, structure elucidation, enzyme-inhibitory and antifouling activities of these compounds.

\section{Results and Discussion}

Compound 1 was obtained as turquoise amorphous solid. Its molecular formula of $\mathrm{C}_{19} \mathrm{H}_{26} \mathrm{O}_{7}$ was determined by HRESIMS $\left(\mathrm{m} / \mathrm{z} 389.1592[\mathrm{M}+\mathrm{Na}]^{+}\right)$. The ${ }^{1} \mathrm{H}$ NMR spectrum exhibited five methyl signals at $\delta_{\mathrm{H}} 1.01$ (d, $\left.J=6.5 \mathrm{~Hz}, \mathrm{Me}-11\right), 1.15$ (s, Me-19), 1.16 (s, Me-20), 1.18 (d, $J=6.5 \mathrm{~Hz}, \mathrm{Me}-12$ ), $1.92(\mathrm{~s}, \mathrm{Me}-13)$, and two oxymethine protons at $\delta_{\mathrm{H}} 3.85(\mathrm{qd}, J=2.0,6.5 \mathrm{~Hz}, \mathrm{H}-3), 5.07$ (dd, $J=2.0$, 
9.5 Hz, H-1). The ${ }^{13} \mathrm{C}$ NMR and DEPT spectra revealed the presence of 19 carbon signals including five methyls [ $\delta_{\mathrm{C}} 9.5$ (Me-13), 18.2 (Me-11), 19.9 (Me-12), 29.4 (overlapped, Me-19 and Me-20)], two methylenes [ $\left.\delta_{\mathrm{C}} 49.8(\mathrm{C}-15), 55.5(\mathrm{C}-17)\right]$, three methines [ $\delta_{\mathrm{C}} 35.0(\mathrm{C}-4), 65.3(\mathrm{C}-1), 71.5(\mathrm{C}-3)$ ], one oxyquaternary carbon $\left(\delta_{\mathrm{C}} 68.5, \mathrm{C}-18\right)$, one fully substituted phenyl ring $\left[\delta_{\mathrm{C}} 101.7(\mathrm{~s}, \mathrm{C}-7), 109.4\right.$ (s, C-5), 110.6 (s, C-9), 139.5 (s, C-10), 155.7 (s, C-8), 158.4 (s, C-6)], one carboxyl group ( $\delta_{\mathrm{C}} 175.5$, $\mathrm{C}-14)$, and one carbonyl group $\left(\delta_{\mathrm{C}} 209.0, \mathrm{C}-16\right)$. These data showed close similarity to those of 3 [6], which suggested that $\mathbf{1}$ had a citrinin skeleton. Comparison of the NMR data of $\mathbf{1}$ and $\mathbf{3}$ showed that the obvious difference between them was the additional appearance of one methyl $\left(\delta_{C} 29.4\right)$, one methylene $\left(\delta_{\mathrm{C}} 55.5\right)$, and one oxyquaternary carbon $\left(\delta_{\mathrm{C}} 68.5\right)$ in 1 , which indicated that the only difference between $\mathbf{1}$ and $\mathbf{3}$ was the side chain substituted at $\mathrm{C}-1$.

This was proved by the HMBC spectrum of 1 (Figure 2). The HMBC correlations of Me-19 with C-17/C-18/C-20, Me-20 with C-17/C-18/C-19, H-17 with C-16/C-18/C-19/C-20, H-15 with C-1/C-16, and $\mathrm{H}-1$ with $\mathrm{C}-9 / \mathrm{C}-15 / \mathrm{C}-16$, suggested the attachment of a $\left(\mathrm{CH}_{3}\right)_{2} \mathrm{C}(\mathrm{OH})-\mathrm{CH}_{2}-\mathrm{CO}-\mathrm{CH}_{2}-$ group at $\mathrm{C}-1$. The relative configuration of $\mathbf{1}$ was further determined by NOESY spectrum (Figure 2). The NOE correlation of H-3 with Me-12 suggested the $\alpha$-configuration of H-3 and Me-12, while the NOE correlations of Me-11 with $\mathrm{H}-1 / \mathrm{H}-4$ suggested that $\mathrm{H}-1, \mathrm{H}-4$ and Me-11 possesed $\beta$-configuration. Its relative configuration was identical to that of compound $\mathbf{3}$ according to their identical NOE data. The specific optical rotation value of $\mathbf{1}\left([\alpha]_{\mathrm{D}}^{2} 24.8(c 0.08, \mathrm{MeOH})\right)$ was also similar to that of $\mathbf{3}\left([\alpha]_{\mathrm{D}}^{2} 59.2\right.$ $(c 0.37, \mathrm{MeOH})$ ), which suggested that the absolute configuration of 1 was $1 R, 3 R, 4 S$. So, the structure of 1 was elucidated as shown and named penicitrinol $\mathrm{F}$.

Figure 2. Key HMBC and NOESY correlations of 1, 2, 8 and 9.

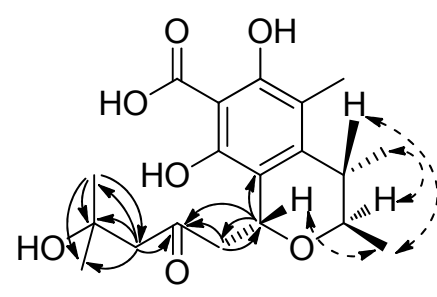

1

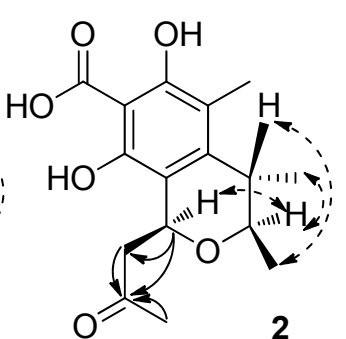

2

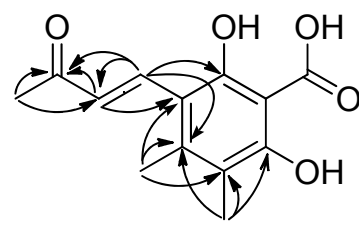

8

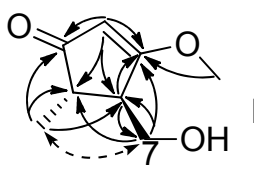

HMBC
NOESY

9

Compound 2 has the same molecular formula of $\mathrm{C}_{16} \mathrm{H}_{20} \mathrm{O}_{6}$ as $\mathbf{3}$, which was inferred from HRESIMS $\left(\mathrm{m} / \mathrm{z} 331.1171[\mathrm{M}+\mathrm{Na}]^{+}\right)$. The ${ }^{1} \mathrm{H}$ and ${ }^{13} \mathrm{C}$ NMR spectroscopic data of 2 showed great similarity to those of 3 [6], except the obvious chemical shift changes of two signals [ $\delta_{C} 68.5(d, C-1), 73.7$ (d, C-3) in 3, and correspondingly $\delta_{\mathrm{C}} 65.5(\mathrm{~d}, \mathrm{C}-1), 71.7(\mathrm{~d}, \mathrm{C}-3)$ in 2]. Further detailed analysis of HSQC and HMBC spectra (Figure 2) suggested that $\mathbf{2}$ should have the same plane structure as $\mathbf{3}$, and it might be an isomer of 3 at C-1. This was supported by the NOESY spectrum of $\mathbf{2}$ (Figure 2). The NOE correlations of H-3 with $\mathrm{H}-1 / \mathrm{Me}-12$ indicated that $\mathrm{H}-1, \mathrm{H}-3$, and Me-12 possessed $\alpha$-configuration, while the NOE correlation of $\mathrm{H}-4$ with Me-11 suggested that $\mathrm{H}-4$ and Me- 11 possessed $\beta$-configuration. By comparison with that of $\mathbf{3}$, the absolute configuration of $\mathbf{2}$ was deduced as $1 R, 3 R, 4 S$. Therefore, the structure of $\mathbf{2}$ was determined as shown. Because the only structural difference between 2 and penicitrinol C [19] was the additional substituent of a carboxyl group at C-7 in 2, so 2 was named 7-carboxypenicitrinol C.

Compound 8 has a molecular formula of $\mathrm{C}_{13} \mathrm{H}_{14} \mathrm{O}_{5}$ as inferred from HRESIMS $(\mathrm{m} / \mathrm{z} 251.0666$ $\left.[\mathrm{M}+\mathrm{H}]^{+}\right)$. The ${ }^{1} \mathrm{H}$ NMR spectrum showed three methyls at $\delta_{\mathrm{H}} 2.00$ (s, Me-13), 2.23 (s, Me-11), 2.27 
(s, Me-12), two olefin protons at $\delta_{\mathrm{H}} 7.02(\mathrm{~d}, J=16.0 \mathrm{~Hz}, \mathrm{H}-9), 7.77(\mathrm{~d}, J=16.0 \mathrm{~Hz}, \mathrm{H}-8)$ and two hydroxyl groups at $\delta_{\mathrm{H}} 15.70(2-\mathrm{OH}), 16.23(6-\mathrm{OH})$. The ${ }^{13} \mathrm{C}$ NMR spectrum showed the presence of three methyls $\left[\delta_{\mathrm{C}} 11.2(\mathrm{Me}-13), 16.6(\mathrm{Me}-12), 27.5(\mathrm{Me}-11)\right]$, six aromatic quaternary carbons $\left[\delta_{\mathrm{C}} 101.3\right.$ (C-1), 109.8 (C-3), 112.7 (C-5), 141.1 (C-4), 162.5 (C-2), 162.6 (C-6)], one double bond [ $\delta_{\mathrm{C}} 125.5$ (d, C-9), 138.6 (d, C-8)], one carboxyl carbon $\left(\delta_{\mathrm{C}} 175.5, \mathrm{C}-7\right)$, and one carbonyl carbon $\left(\delta_{\mathrm{C}} 198.3, \mathrm{C}-10\right)$. These NMR data showed similarity to those of 7 [9], which suggested that 8 was a fully substituted benzoic acid derivative. In the HMBC spectrum (Figure 2), the correlations of Me-11 with C-9/C-10, $\mathrm{H}-8$ with $\mathrm{C}-2 / \mathrm{C}-4 / \mathrm{C}-9 / \mathrm{C}-10$, and $\mathrm{H}-9$ with $\mathrm{C}-3 / \mathrm{C}-10$, suggested $\mathrm{CH}_{3}-\mathrm{CO}-\mathrm{CH}=\mathrm{CH}-$ group attached at $\mathrm{C}-3$ of the aromatic ring. A large coupling constant between $\mathrm{H}-8$ and $\mathrm{H}-9\left(J_{8,9}=16.0 \mathrm{~Hz}\right)$ indicated $E$-configuration of the double bond. Furthermore, the HMBC correlations of Me-13 with C-4/C-5/C-6, and Me-12 with C-3/C-4/C-5, suggested two methyl groups attached at C-4 and C-5, respectively. Based on the above data, the structure of $\mathbf{8}$ was determined as shown and named 2, 6-dihydroxy-4,5-dimethyl-3-(3-oxo-1-butenyl)benzoic acid.

Compound 9 has a molecular formula of $\mathrm{C}_{8} \mathrm{H}_{12} \mathrm{O}_{3}$ as inferred from HRESIMS $(\mathrm{m} / \mathrm{z} 157.0854$ $\left.[\mathrm{M}+\mathrm{H}]^{+}\right)$. The ${ }^{1} \mathrm{H}$ NMR spectrum exhibited one methyl at $\delta_{\mathrm{H}} 1.06(\mathrm{~d}, J=7.5 \mathrm{~Hz}, \mathrm{H}-8)$, two methines at $\delta_{\mathrm{H}} 2.32(\mathrm{qd}, J=7.5,3.0 \mathrm{~Hz}, \mathrm{H}-5), 2.47$ (ddd, $\left.J=1.0,3.0,6.5 \mathrm{~Hz}, \mathrm{H}-4\right)$, one oxymethylene at $\delta_{\mathrm{H}} 3.61$ (m, H-7), one oxymethyl at $\delta_{\mathrm{H}} 3.80$ (s, H-6) and one olefinic methine at $\delta_{\mathrm{H}} 5.32$ (s, H-2). The ${ }^{13} \mathrm{C} \mathrm{NMR}$ and DEPT spectra revealed the presence of eight carbons including one methyl $\left(\delta_{\mathrm{C}} 15.3\right.$, Me-8), two methines [ $\left.\delta_{\mathrm{C}} 42.8(\mathrm{C}-4), 50.9(\mathrm{C}-5)\right]$, one oxymethyl ( $\left.\delta_{\mathrm{C}} 58.7, \mathrm{C}-6\right)$, one oxymethylene $\left(\delta_{\mathrm{C}} 59.5, \mathrm{C}-7\right)$, one double bond $\left[\delta_{\mathrm{C}} 103.4(\mathrm{~d}, \mathrm{C}-2), 188.8\right.$ (s, C-3)], and one carbonyl group $\left(\delta_{\mathrm{C}} 205.9, \mathrm{C}-1\right)$. Furthermore, the HMBC spectrum (Figure 2) showed that the correlations of H-8 with C-1/C-4/C-5, H-7 with C-3/C-4/C-5, H-6 with C-3, H-2 with C-1/C-3/C-4/C-5, and H-4 with C-3/C-7, which established the plane structure of 9 . The relative configuration of 9 was further assigned by NOESY spectrum. The NOE correlation of H-7 with H-5 suggested that protons H-4 and H-5 were on the different side, which was supported by the coupling constant between H-4 and H-5 $\left(J_{4,5}=3.0 \mathrm{~Hz}\right)$. Based on the above data, the structure of 9 was determined as shown and named 4-(hydroxymethyl)-3-methoxy-5-methyl cyclopent-2-enone. It is interesting that $\mathbf{9}$ has the same cyclopent-2-enone skeleton as cyclopentenone prostaglandins those are commonly present in many species of gorgonians [20].

Compound $\mathbf{1 0}$ has a molecular formula of $\mathrm{C}_{19} \mathrm{H}_{22} \mathrm{O}_{8}$ as inferred from HRESIMS $(\mathrm{m} / z$ 401.1209 $\left.[\mathrm{M}+\mathrm{Na}]^{+}\right)$. The ${ }^{1} \mathrm{H}$ NMR spectrum exhibited signals for one methyl at $\delta_{\mathrm{H}} 2.17(\mathrm{~s})$, seven sugar protons at $\delta_{\mathrm{H}} 3.59-4.81$ [3.59 (1H, m, H-2'), $3.71\left(1 \mathrm{H}, \mathrm{m}, \mathrm{H}^{-} 4^{\prime}\right), 3.72\left(1 \mathrm{H}, \mathrm{m}, \mathrm{H}-5^{\prime}\right), 3.82\left(1 \mathrm{H}, \mathrm{t}, J=9.5, \mathrm{H}-3^{\prime}\right)$, $4.44\left(1 \mathrm{H}, \mathrm{dd}, J=1.5,12.5 \mathrm{~Hz}, \mathrm{H}-6{ }^{\prime} \mathrm{a}\right), 4.62\left(1 \mathrm{H}, \mathrm{dd}, J=4.5,12.5 \mathrm{~Hz}, \mathrm{H}-6{ }^{\prime} \mathrm{b}\right), 4.81(1 \mathrm{H}, \mathrm{d}, J=7.0 \mathrm{~Hz}$, $\left.\mathrm{H}-1^{\prime}\right)$ ], one oxymethyl at $\delta_{\mathrm{H}} 4.00(\mathrm{~s}, \mathrm{Me}-11)$, and six protons of aromatic $\mathrm{ABC}$ and $\mathrm{A}^{\prime} \mathrm{B}^{\prime} \mathrm{C}^{\prime}$ systems at $\delta_{\mathrm{H}}$ $6.96(1 \mathrm{H}, \mathrm{d}, J=8.0 \mathrm{~Hz}, \mathrm{H}-2), 7.36(1 \mathrm{H}, \mathrm{br} \mathrm{t}, J=8.0 \mathrm{~Hz}, \mathrm{H}-3), 7.38(1 \mathrm{H}, \mathrm{br} \mathrm{t}, J=8.0 \mathrm{~Hz}, \mathrm{H}-6), 7.41(1 \mathrm{H}$, $\mathrm{dd}, J=2.5,8.0 \mathrm{~Hz}, \mathrm{H}-4), 7.48(1 \mathrm{H}, \mathrm{d}, J=8.0 \mathrm{~Hz}, \mathrm{H}-7), 7.58(1 \mathrm{H}, \mathrm{dd}, J=2.5,8.0 \mathrm{~Hz}, \mathrm{H}-5)$. The ${ }^{13} \mathrm{C} \mathrm{NMR}$ and DEPT spectra revealed the presence of 19 carbon signals including one methyl $\left(\delta_{\mathrm{C}} 20.9\right.$, Me-13), one oxymethyl $\left(\delta_{\mathrm{C}} 57.2\right.$, Me-11), a sugar moiety [ $\delta_{\mathrm{C}} 63.3\left(\mathrm{t}, \mathrm{C}-6^{\prime}\right), 69.9\left(\mathrm{~d}, \mathrm{C}-4^{\prime}\right), 74.0\left(\mathrm{~d}, \mathrm{C}-3^{\prime}\right), 74.5$ $\left.\left(\mathrm{d}, \mathrm{C}-5^{\prime}\right), 75.8\left(\mathrm{~d}, \mathrm{C}-2^{\prime}\right), 105.1\left(\mathrm{~d}, \mathrm{C}-1^{\prime}\right)\right]$, ten aromatic carbons $\left[\delta_{\mathrm{C}} 108.5(\mathrm{~d}, \mathrm{C}-2), 114.7(\mathrm{~d}, \mathrm{C}-7), 118.4\right.$ (s, C-9), 122.1 (d, C-4), 124.2 (d, C-5), 126.4 (d, C-6), 126.5 (d, C-3), 136.2 (s, C-10), 155.0 (s, C-1), $155.6(\mathrm{~s}, \mathrm{C}-8)]$, and one carboxyl group $\left[\delta_{\mathrm{C}} 171.6\left(\mathrm{COOCH}_{3}\right)\right]$. These NMR data showed remarkable similarity to those of $\mathbf{1 1}$ [10], and the only difference between $\mathbf{1 0}$ and $\mathbf{1 1}$ was the additional presence of one acetyl group in 10, which suggested that $\mathbf{1 0}$ had the same structural skeleton as $\mathbf{1 1}$ and the sugar 
moiety was glucose $[10,21]$. In the HMBC spectrum, the correlations of $\mathrm{H}-6^{\prime}$ with $\mathrm{C}-12$, and Me-13 with $\mathrm{C}-12$ suggested the acetylation of $6^{\prime}-\mathrm{OH}$ of the glucose moiety. The large coupling constant of $7.0 \mathrm{~Hz}$ for the anomeric proton of the glucose moiety $\left(\delta_{\mathrm{H}} 4.81\right)$ suggested that the glucose was $\beta$-glucose $[10,21,22]$. Therefore, the structure of $\mathbf{1 0}$ was determined as shown and named 8-methoxy-1-naphthyl 6'-O-acetyl- $\beta$-glucopyranoside.

Compounds 1-18 were tested for their inhibitory activities towards enzymes of cathepsin B, IMPDH, PTPIB and SHP2. The results displayed that $\mathbf{4}$ and 7 had inhibitory activities towards cathepsin B with $\mathrm{IC}_{50}$ values of $28.5 \pm 1.7,20.4 \pm 1.9 \mu \mathrm{M}$, respectively, $\mathbf{6}$ showed inhibitory activities towards SHP2 and IMPDH with $\mathrm{IC}_{50}$ values of $58.4 \pm 4.0$ and $98.7 \pm 6.2 \mu \mathrm{M}$, respectively, and 17 showed inhibitory activities towards SHP2, PTPIB, and IMPDH with $\mathrm{IC}_{50}$ values of $4.1 \pm 0.6,13.9 \pm 1.8$, and $41.2 \pm 3.6 \mu \mathrm{M}$, respectively, while other compounds showed very weak or no activity towards all tested enzymes. The positive controls used in cathepsin B and IMPDH enzyme-inhibitory assays were leupeptin and mycophenolic acid, with $\mathrm{IC}_{50}$ values of 0.03 and $0.4 \mu \mathrm{M}$, respectively. Similarly, the ursolic acid used as positive controls in PTPIB and SHP2 enzyme-inhibitory assays showed an identical $\mathrm{IC}_{50}$ value of $2.8 \mu \mathrm{M}$. Cathepsin B and SHP2 are targets for screening anti-tumor agents, and IMPDH and PTPIB are targets for screening immunosuppressive and anti-diabetic agents, respectively. Previous studies reported that 17 was a phytotoxic substance and an important melanin biosynthetic intermediate in fungi [23]. Moreover, 17 was found to be a SHP2 and PTPIB inhibitor. This is the first time that the enzyme-inhibitory activities of these compounds has been reported.

In addition, antifouling activities of compounds 1-18 were tested against larvae settlement of $B$. neritina larva. The results showed that $\mathbf{6}$ and 7 had strong antifouling activity against $B$. neritina larvae settlement with $\mathrm{EC}_{50}$ values of $1.76 \pm 0.8$ and $14.35 \pm 1.72 \mu \mathrm{g} / \mathrm{mL}$, and $\mathrm{LC}_{50} / \mathrm{EC}_{50}$ values of $>56$, and $>15$, respectively, while other compounds showed weak or no activity. Usually, the standard requirement of an efficacy $\mathrm{EC}_{50}$ level for natural antifoulant is $25 \mu \mathrm{g} / \mathrm{mL}$, and an antifouling compound with $\mathrm{LC}_{50} / \mathrm{EC}_{50}>15$ is often considered as a non-toxic antifouling compound [24]. The results indicated that 6 and 7 were potential natural antifouling candidates. This is the first time that the antifouling activities of these compounds has been reported.

\section{Experimental Section}

\subsection{General Experimental Procedures}

Optical rotations were measured with a PL341 spectropolarimeter. UV spectra were measured with a Shimadzu UV-2501PC spectrophotometer in MeOH solution. IR spectra were measured with a FT-IR NICOLET spectrophotometer. ${ }^{1} \mathrm{H},{ }^{13} \mathrm{C}$ NMR and 2D NMR spectra were recorded on a Bruker AV-500 $\mathrm{MHz}$ NMR spectrometer with TMS as reference. MS spectroscopic data were obtained on a LCQDECA XP HPLC/MSn spectrometer for ESIMS. High-resolution electrospray-ionization (HRESIMS) was performed on a UPLC/Q-TOF Micro MS spectrometer under $70 \mathrm{eV}$. Semi-preparative HPLC was performed on a Shimadzu LC-20A preparative liquid chromatography with an YMC-Pack ODS column, $250 \times 10 \mathrm{~mm}$ i.d., S-5 $\mu \mathrm{m}$. Sephadex LH-20 (GE Healthcare) was used for CC. Silica gel (200-300 mesh) for CC and GF254 for TLC were obtained from the Qindao Marine Chemical Factory, Qindao, China. 


\subsection{Fungal Material}

The fungal strain SCSGAF0086 (GenBank access number JN851017) was isolated from the South China Sea gorgonian corals Melitodes squamata, and identified as Xylariaceae sp. SCSGAF0086 by a molecular biological protocol calling for DNA amplification and ITS region sequence comparison with GenBank database, sharing a similarity of $89 \%$ with Xylariaceae sp., which was deposited in RNAM center, South China Sea Institute of Oceanology, Chinese Academy of Sciences.

\subsection{Fermentation and Extraction}

The strain was inoculated in PDA liquid medium (containing $20 \mathrm{~g} / \mathrm{L}$ glucose, $200 \mathrm{~g} / \mathrm{L}$ potato and $30 \mathrm{~g} / \mathrm{L}$ sea salt) in $500 \mathrm{~mL}$ shake flask loading $120 \mathrm{~mL}$ as seed culture and incubated on a rotary shaker ( $200 \mathrm{rpm}$ ) at $28^{\circ} \mathrm{C}$ for 3 days. Then, $20 \mathrm{~L}$ broth inoculated with seed culture as scale-up cultivation were carried out under static condition at $28^{\circ} \mathrm{C}$ for 50 days in 120 of $500-\mathrm{mL}$ conical flasks containing the liquid medium (150 mL/flask) composed of glucose $(10 \mathrm{~g} / \mathrm{L})$, maltose $(20 \mathrm{~g} / \mathrm{L})$, mannitol (20 g/L), monosodium glutamate $(10 \mathrm{~g} / \mathrm{L}), \mathrm{KH}_{2} \mathrm{PO}_{4}(0.5 \mathrm{~g} / \mathrm{L}), \mathrm{MgSO}_{4} \cdot 7 \mathrm{H}_{2} \mathrm{O}(0.3 \mathrm{~g} / \mathrm{L})$, corn steep liquor $(0.5 \mathrm{~g} / \mathrm{L})$, yeast extract $(3 \mathrm{~g} / \mathrm{L})$, and seawater (adjusted to $\mathrm{pH} 7.0$ with $1 \mathrm{~mol} / \mathrm{L}$ hydrochloric acid before sterilization).

After incubation, the $20 \mathrm{~L}$ fermentation broth was filtered through cheesecloth to separate the broth supernatant and mycelia, respectively. For fermentation broth, the supernatant was extracted with ethyl acetate while mycelia was extracted with $80 \%$ acetone; the acetone extract was evaporated under reduced pressure to afford an aqueous solution, and extracted with ethyl acetate; The extracts of filtrate and mycelium were concentrated in vacuo to give a crude residue.

\subsection{Isolation and Purification}

The residue $(10.5 \mathrm{~g})$ was subjected to a reversed phase RP-18 CC eluting with $\mathrm{MeOH}-\mathrm{H}_{2} \mathrm{O}$ solvent system at the ratios of 100:0, 80:20, 65:35, 45:55, 25:75, 0:100 (v/v) to yield 11 fractions. Fraction 3 (234 mg) was subjected to repeated Sephadex LH-20 CC eluting with MeOH to obtain 18 (2.3 mg). Fraction $4(640 \mathrm{mg})$ was fractionated by Sephadex LH-20 CC eluting with MeOH to offer six subfractions (4-1-4-6), and then subfraction 4-1 was purified by semi-preparative reversed-phase (SP-RP) HPLC (YMC-Pack, ODS S-5 $\mu 250 \times 10 \mathrm{~mm}$ i.d., $3 \mathrm{~mL} / \mathrm{min}$ ) eluting with $\mathrm{MeOH}-\mathrm{H}_{2} \mathrm{O}(20: 80)$ to give 9 $(1.2 \mathrm{mg})$, further purification of subfraction 4-2 was achieved by preparative TLC with a mobile phase of $\mathrm{CHCl}_{3}-\mathrm{MeOH}$ (8:2) to give $\mathbf{1 2}(5.3 \mathrm{mg}), \mathbf{1 5}(3.3 \mathrm{mg})$, and $\mathbf{1 7}(20.3 \mathrm{mg})$, subfraction 4-4 was purified by a silica gel $\mathrm{CC}$ eluting with $\mathrm{CHCl}_{3}-\mathrm{MeOH}$ at the ratios of 95:5, 90:10, 80:20, 70:30 (v:v), to offer 7 (4.6 mg), and subfraction 4-6 was purified by SP-RP-HPLC with MeOH- $\mathrm{H}_{2} \mathrm{O}-\mathrm{TFA}$ (30:70:0.03) to obtain 4 (8.9 mg). Fraction $5(260 \mathrm{mg})$ was separated by Sephadex LH-20 CC to afford seven subfractions. Subfraction 5-5 was purified by SP-RP-HPLC eluting with $\mathrm{MeOH}-\mathrm{H}_{2} \mathrm{O}$ (30:70) to obtain $13(8.2 \mathrm{mg})$ and $14(6.9 \mathrm{mg})$. Subfraction 5-6 was subjected to Sephadex LH-20 CC to give a mixture of isomers 2 and 3, and the mixture was further purified by SP-RP-HPLC, eluting with $\mathrm{MeOH}-\mathrm{H}_{2} \mathrm{O}-\mathrm{TFA}$ (47:53:0.03) to afford $2\left(2.8 \mathrm{mg}, t_{R}=16 \mathrm{~min}\right)$ and $\mathbf{3}\left(4.8 \mathrm{mg}, t_{R}=20 \mathrm{~min}\right)$. Subfraction 5-7 was purified by repeated Sephadex LH-20 CC to obtain $8(2.9 \mathrm{mg})$. Fraction $6(100 \mathrm{mg})$ was subjected to repeated Sephadex LH-20 CC eluting with MeOH to obtain 1 (3.5 mg), and 16 (7.4 mg). Fraction 7 (460 mg) was 
fractionated by Sephadex LH-20 CC, then further purified by SP-RP-HPLC using $\mathrm{MeOH}-\mathrm{H}_{2} \mathrm{O}$ (45:55) to give $5(2.3 \mathrm{mg})$ and $\mathbf{1 1}(4.3 \mathrm{mg})$. Fraction $8(565 \mathrm{mg})$ was fractionated by repeated Sephadex LH-20 $\mathrm{CC}$ eluting with $\mathrm{MeOH}$ to give $\mathbf{1 0}(2.9 \mathrm{mg})$. Fraction $9(410 \mathrm{mg})$ was subjected to Sephadex LH-20 CC, then purified by SP-RP-HPLC eluting with $\mathrm{MeOH}-\mathrm{H}_{2} \mathrm{O}$ (70:30) to afford 6 (2.3 $\mathrm{mg}$ ).

Penicitrinol F (1): Turquoise amorphous solid; $[\alpha]_{D}^{2} 24.8(c 0.08, \mathrm{MeOH}) ; \mathrm{UV}(\mathrm{MeOH}) \lambda_{\max }(\log \varepsilon)$ : $383(2.15) \mathrm{nm}$; IR (KBr) v $v_{\text {max }}: 3417,2975,2932,1686,1626,1595,1497,1427,1407,1382,1208 \mathrm{~cm}^{-1}$; ${ }^{1} \mathrm{H}-\mathrm{NMR}\left(500 \mathrm{MHz}, \mathrm{DMSO}-d_{6}\right) \delta_{\mathrm{H}}: 15.18(1 \mathrm{H}$, br s, 8-OH), $14.67(1 \mathrm{H}$, br s, 6-OH), $5.07(1 \mathrm{H}$, dd, $J=2.0,9.5 \mathrm{~Hz}, \mathrm{H}-1), 4.47(1 \mathrm{H}$, br s, $18-\mathrm{OH}), 3.85(1 \mathrm{H}, \mathrm{qd}, J=2.0,6.5 \mathrm{~Hz}, \mathrm{H}-3), 3.23(1 \mathrm{H}, \mathrm{dd}, J=2.0$, $\left.15.3 \mathrm{~Hz}, \mathrm{CH}_{2}-15\right), 2.63\left(1 \mathrm{H}, \mathrm{dd}, J=9.5,15.3 \mathrm{~Hz}, \mathrm{CH}_{2}-15\right), 2.56\left(2 \mathrm{H}, \mathrm{s}, \mathrm{CH}_{2}-17\right), 2.53(1 \mathrm{H}, \mathrm{qd}, J=2.0$, $6.5 \mathrm{~Hz}, \mathrm{H}-4), 1.92$ (3H, s, Me-13), 1.18 (3H, d, J=6.5 Hz, Me-12), 1.16 (3H, s, Me-20), 1.15 (3H, s, Me-19), 1.01 (3H, d, $J=6.5 \mathrm{~Hz}, \mathrm{Me}-11) ;{ }^{13} \mathrm{C}-\mathrm{NMR}$ (125 MHz, DMSO- $\left.d_{6}\right) \delta_{\mathrm{C}}: 209.0$ (C, C-16), 175.5 (C, C-14), 158.4 (C, C-6), 155.7 (C, C-8), 139.5 (C, C-10), 110.6 (C, C-9), 109.4 (C, C-5), 101.7 (C, C-7), 71.5 (CH, C-3), $68.5(\mathrm{C}, \mathrm{C}-18), 65.3(\mathrm{CH}, \mathrm{C}-1), 55.5\left(\mathrm{CH}_{2}, \mathrm{C}-17\right), 49.8\left(\mathrm{CH}_{2}, \mathrm{C}-15\right), 35.0(\mathrm{CH}$, C-4), $29.4\left(\mathrm{CH}_{3}\right.$, overlapped, $\mathrm{C}-19$ and C-20), $19.9\left(\mathrm{CH}_{3}, \mathrm{C}-12\right), 18.2\left(\mathrm{CH}_{3}, \mathrm{C}-11\right), 9.5\left(\mathrm{CH}_{3}, \mathrm{C}-13\right)$; HRESIMS $m / z 389.1592[\mathrm{M}+\mathrm{Na}]^{+}$(calcd. for $\mathrm{C}_{19} \mathrm{H}_{26} \mathrm{NaO}_{7}, 389.1576$ ).

7-Carboxypenicitrinol C (2): Yellow amorphous solid; $[\alpha]_{\mathrm{D}}^{2}-31.7$ (c 0.42, $\left.\mathrm{MeOH}\right) ; \mathrm{UV}(\mathrm{MeOH})$ $\lambda_{\max }(\log \varepsilon): 215(3.15), 252(2.65), 320(2.19) \mathrm{nm}$; IR (KBr) $v_{\max }: 3427,2973,2931,2832,2718,1698$, 1591, 1418, 1364, $1264 \mathrm{~cm}^{-1}$; ${ }^{1} \mathrm{H}-\mathrm{NMR}\left(500 \mathrm{MHz}, \mathrm{DMSO}-d_{6}\right) \delta_{\mathrm{H}}: 14.91(1 \mathrm{H}, \mathrm{br} \mathrm{s}, 8-\mathrm{OH}), 14.41(1 \mathrm{H}$, br s, 6-OH), $5.08(1 \mathrm{H}, \mathrm{dd}, J=3.0,9.5 \mathrm{~Hz}, \mathrm{H}-1), 3.87(1 \mathrm{H}, \mathrm{qd}, J=1.0,6.5 \mathrm{~Hz}, \mathrm{H}-3), 3.44(1 \mathrm{H}, \mathrm{dd}, J=3.0$, 14.7 Hz, H-15a), 2.55 (1H, qd, $J=1.0,7.0 \mathrm{~Hz}, \mathrm{H}-4), 2.48$ (1H, dd, $J=9.5,14.7 \mathrm{~Hz}, \mathrm{H}-15 \mathrm{~b}), 2.12$ (3H, s, Me-17), 1.93 (3H, s, Me-13), 1.19 (3H, d, $J=7.0 \mathrm{~Hz}, \mathrm{Me}-12), 1.03$ (3H, d, $J=6.5 \mathrm{~Hz}, \mathrm{Me}-11)$; ${ }^{13} \mathrm{C}-\mathrm{NMR}\left(125 \mathrm{MHz}, \mathrm{DMSO}-d_{6}\right) \delta_{\mathrm{C}}: 207.4$ (C, C-16), 175.8 (C, C-14), 158.4 (C, C-6), 155.6 (C, C-8), 140.0 (C, C-10), 110.7 (C, C-9), 109.8 (C, C-5), 101.4 (C, C-7), 71.7 (CH, C-3), 65.5 (CH, C-1), 49.1 $\left(\mathrm{CH}_{2}, \mathrm{C}-15\right), 35.1$ (CH, C-4), $30.0\left(\mathrm{CH}_{3}, \mathrm{C}-17\right), 20.0\left(\mathrm{CH}_{3}, \mathrm{C}-11\right), 18.2\left(\mathrm{CH}_{3}, \mathrm{C}-12\right), 9.5\left(\mathrm{CH}_{3}, \mathrm{C}-13\right)$; HRESIMS $m / z 331.1171[\mathrm{M}+\mathrm{Na}]^{+}$(calcd. for $\mathrm{C}_{16} \mathrm{H}_{20} \mathrm{NaO}_{6}, 331.1158$ ).

2,6-Dihydroxy-4,5-dimethyl-3-(3-oxo-1-butenyl) benzoic acid (8): Yellow amorphous solid; UV $(\mathrm{MeOH}) \lambda_{\max }(\log \varepsilon): 214(2.50), 249(2.43), 372(2.37) \mathrm{nm}$; IR (KBr) $v_{\max }: 3434,2922,1581,1406,1364$, 1256, 1497, 1228, $1155 \mathrm{~cm}^{-1}$; ${ }^{1} \mathrm{H}-\mathrm{NMR}\left(500 \mathrm{MHz}, \mathrm{DMSO}-d_{6}\right) \delta_{\mathrm{H}}: 16.23(1 \mathrm{H}, \mathrm{s}, 2-\mathrm{OH}), 15.70(1 \mathrm{H}, \mathrm{s}$, 6-OH), 7.77 (1H, d, $J=16.0 \mathrm{~Hz}, \mathrm{H}-8), 7.02(1 \mathrm{H}, \mathrm{d}, J=16.0 \mathrm{~Hz}, \mathrm{H}-9), 2.27$ (3H, s, Me-12), 2.23 (3H, s, Me-11), 2.00 (3H, s, Me-13); ${ }^{13} \mathrm{C}-\mathrm{NMR}\left(125 \mathrm{MHz}, \mathrm{DMSO}-d_{6}\right) \delta_{\mathrm{C}}: 198.3$ (C, C-10), 175.5 (C, C-7), 162.6 (C, C-6), 162.5 (C, C-2), 141.1 (C, C-4), 138.6 (CH, C-8), 125.5 (CH, C-9), 112.7 (C, C-5), 109.8 (C, C-3), $101.3(\mathrm{C}, \mathrm{C}-1), 27.5\left(\mathrm{CH}_{3}, \mathrm{C}-11\right), 16.6\left(\mathrm{CH}_{3}, \mathrm{C}-12\right), 11.2\left(\mathrm{CH}_{3}, \mathrm{C}-13\right)$; HRESIMS $\mathrm{m} / \mathrm{z}$ 251.0666 [M+ H] $]^{+}$(calcd. for $\mathrm{C}_{13} \mathrm{H}_{15} \mathrm{O}_{5}, 251.0642$ ).

4-(Hydroxymethyl)-3-methoxy-5-methylcyclopent-2-enone (9): White amorphous solid; $[\alpha]^{2}-4.2$ (c 0.12, MeOH); UV (MeOH) $\lambda_{\max }(\log \varepsilon) 237$ (2.93) nm; IR (KBr) $v_{\max }: 3389,2962,2934,2877,1678$, $1590,1515,1455,1439,1383,1360,1255,1195 \mathrm{~cm}^{-1}$; ${ }^{1} \mathrm{H}-\mathrm{NMR}\left(500 \mathrm{MHz}, \mathrm{DMSO}-d_{6}\right) \delta_{\mathrm{H}}: 5.32(1 \mathrm{H}, \mathrm{s}$, $\mathrm{H}-2), 4.77(1 \mathrm{H}, \mathrm{t}, J=5.0 \mathrm{~Hz}, 7-\mathrm{OH}), 3.80\left(3 \mathrm{H}, \mathrm{s}, \mathrm{OCH}_{3}\right), 3.61\left(2 \mathrm{H}, \mathrm{m}, \mathrm{CH}_{2}-7\right), 2.47(1 \mathrm{H}, \mathrm{ddd}, J=1.0$, 3.0, $6.5 \mathrm{~Hz}, \mathrm{H}-4), 2.32(1 \mathrm{H}, \mathrm{qd}, J=7.5,3.0 \mathrm{~Hz}, \mathrm{H}-5), 1.06(3 \mathrm{H}, \mathrm{d}, J=7.5 \mathrm{~Hz}, \mathrm{Me}-8),{ }^{13} \mathrm{C}-\mathrm{NMR}$ $\left(125 \mathrm{MHz}, \mathrm{DMSO}-d_{6}\right) \delta_{\mathrm{C}}: 205.9(\mathrm{C}, \mathrm{C}-1), 188.8$ (C, C-3), $103.4(\mathrm{CH}, \mathrm{C}-2), 59.5\left(\mathrm{CH}_{2}, \mathrm{C}-7\right), 58.7\left(\mathrm{CH}_{3}\right.$, C-6), 50.9 (CH, C-5), 42.8 (CH, C-4), $15.3\left(\mathrm{CH}_{3}, \mathrm{C}-8\right)$; HRESIMS $m / z 157.0854[\mathrm{M}+\mathrm{H}]^{+}$(calcd. for $\left.\mathrm{C}_{8} \mathrm{H}_{13} \mathrm{O}_{3}, 157.0859\right)$. 
8-Methoxy-1-naphthyl 6'-O-acetyl- $\beta$-glucopyranoside (10): Yellow amorphous solid; $[\alpha]_{\mathrm{D}}^{2}-16.6$ (c 0.10, MeOH); UV (MeOH) $\lambda_{\max }(\log \varepsilon) 225(3.47), 284(2.69) \mathrm{nm}$; IR (KBr) $v_{\max }: 3405,2933,1723$, 1660, 1641, 1455, 1381, 1268, $1074 \mathrm{~cm}^{-1}$; ${ }^{1} \mathrm{H}-\mathrm{NMR}\left(500 \mathrm{MHz}, \mathrm{CDCl}_{3}\right) \delta_{\mathrm{H}}: 7.58(1 \mathrm{H}, \mathrm{dd}, J=2.5,8.0 \mathrm{~Hz}$, H-5), $7.48(1 \mathrm{H}, \mathrm{d}, J=8.0 \mathrm{~Hz}, \mathrm{H}-7), 7.41(1 \mathrm{H}, \mathrm{dd}, J=2.5,8.0 \mathrm{~Hz}, \mathrm{H}-4), 7.38(1 \mathrm{H}, \mathrm{br} \mathrm{t}, J=8.0 \mathrm{~Hz}, \mathrm{H}-6)$, $7.36(1 \mathrm{H}$, br t $, J=8.0 \mathrm{~Hz}, \mathrm{H}-3), 6.96(1 \mathrm{H}, \mathrm{d}, J=8.0 \mathrm{~Hz}, \mathrm{H}-2), 4.81\left(1 \mathrm{H}, \mathrm{d}, J=7.0 \mathrm{~Hz}, \mathrm{H}-1^{\prime}\right), 4.62(1 \mathrm{H}$, $\left.\mathrm{dd}, J=4.5,12.5 \mathrm{~Hz}, \mathrm{H}-6^{\prime} \mathrm{b}\right), 4.44\left(1 \mathrm{H}, \mathrm{dd}, J=1.5,12.5 \mathrm{~Hz}, \mathrm{H}-6{ }^{\prime} \mathrm{a}\right), 4.00$ (3H, s, Me-11), 3.82 (1H, t, $\left.J=9.5, \mathrm{H}-3^{\prime}\right), 3.72\left(1 \mathrm{H}, \mathrm{m}, \mathrm{H}-5^{\prime}\right), 3.71\left(1 \mathrm{H}, \mathrm{m}, \mathrm{H}-4^{\prime}\right), 3.59\left(1 \mathrm{H}, \mathrm{m}, \mathrm{H}-2^{\prime}\right), 2.17(3 \mathrm{H}, \mathrm{s}, \mathrm{Me}-13) ;{ }^{13} \mathrm{C}-\mathrm{NMR}$ $\left(125 \mathrm{MHz}, \mathrm{CDCl}_{3}\right) \delta_{\mathrm{C}}: 171.6\left(\mathrm{C}, \mathrm{COOCH}_{3}\right), 155.6(\mathrm{C}, \mathrm{C}-8), 155.0(\mathrm{C}, \mathrm{C}-1), 136.2(\mathrm{C}, \mathrm{C}-10), 126.5(\mathrm{CH}$, C-3), 126.4 (CH, C-6), 124.2 (CH, C-5), 122.1 (CH, C-4), 118.4 (C, C-9), 114.7 (CH, C-7), 108.5 (CH, C-2), $105.1\left(\mathrm{CH}, \mathrm{C}-1^{\prime}\right), 75.8\left(\mathrm{CH}, \mathrm{C}-2^{\prime}\right), 74.5\left(\mathrm{CH}, \mathrm{C}-5^{\prime}\right), 74.0\left(\mathrm{CH}, \mathrm{C}-3^{\prime}\right), 69.9\left(\mathrm{CH}, \mathrm{C}-4^{\prime}\right), 63.3$ $\left(\mathrm{CH}_{2}, \mathrm{C}-6^{\prime}\right), 57.2\left(\mathrm{CH}_{3}, \mathrm{C}-11\right), 20.9\left(\mathrm{CH}_{3}, \mathrm{C}-13\right)$; HRESIMS $\mathrm{m} / z$ 401.1209 [M $\left.+\mathrm{Na}\right]^{+}$(calcd. for $\mathrm{C}_{19} \mathrm{H}_{22} \mathrm{NaO}_{8}, 401.1212$ ).

\subsection{Enzyme-Inhibitory Activity Assays}

Enzyme-inhibitory activity assays were tested according to literatures reported [25-28].

\subsection{Larval Settlement Assays}

Larval culture and larval settlement assays matched the method reported in reference [29].

\section{Conclusions}

In conclusion, our investigation on the chemical constituents of the extract from gorgonian-derived fungal strain Xylariaceae sp. SCSGAF0086 led to the obtainment of 18 polyketides (1-18). Among these compounds, 1, 2, 8, 9, and 10 were new 4, 6, 7, and 17 showed enzyme-inhibitory activities towards several tested enzymes, and $\mathbf{6}$ and $\mathbf{7}$ showed strong antifouling activity against $B$. neritina larvae settlement. This is the first time that the antifouling and enzyme-inhibitory activities of these compounds has been reported.

\section{Acknowledgments}

The authors are grateful to 973 Program of China (2010CB833803), 863 Program of China (2012AA092104), National Marine Public Welfare Research Project of China (grant 201305017), and National Natural Science Foundation of China (40931160435 and 40976090) for financial support.

\section{Conflict of Interest}

The authors declare no conflict of interest.

\section{References}

1. Du, L.; Zhu, T.; Fang, Y.; Liu, H.; Gu, Q.; Zhu, W. Aspergiolide A, a novel anthraquinone derivative with naphtho 1,2,3-de chromene-2,7-dione skeleton isolated from a marine-derived fungus Aspergillus glaucus. Tetrahedron 2007, 63, 1085-1088. 
2. Ishino, M.; Kiyomichi, N.; Takatori, K.; Sugita, T.; Shiro, M.; Kinoshita, K.; Takahashi, K.; Koyama, K. Phomactin I, 13-epi-Phomactin I, and Phomactin J, three novel diterpenes from a marine-derived fungus. Tetrahedron 2010, 66, 2594-2597.

3. Shao, C.L.; Wang, C.Y.; Gu, Y.C.; Wei, M.Y.; Pan, J.H.; Deng, D.S.; She, Z.G.; Lin, Y.C. Penicinoline, a new pyrrolyl 4-quinolinone alkaloid with an unprecedented ring system from an endophytic fungus Penicillium sp. Bioorg. Med. Chem. Lett. 2010, 20, 3284-3286.

4. Shao, C.L.; Wu, H.X.; Wang, C.Y.; Liu, Q.A.; Xu, Y.; Wei, M.Y.; Qian, P.Y.; Gu, Y.C.; Zheng, C.J.; She, Z.G.; et al. Potent antifouling resorcylic acid lactones from the gorgonian-derived fungus Cochliobolus lunatus. J. Nat. Prod. 2011, 74, 629-633.

5. Wei, M.Y.; Wang, C.Y.; Liu, Q.A.; Shao, C.L.; She, Z.G.; Lin, Y.C. Five sesquiterpenoids from a marine-derived fungus Aspergillus sp. isolated from a gorgonian Dichotella gemmacea. Mar. Drugs 2010, 8, 941-949.

6. Xu, L.; Xue, J.; Xu, H.; Liu, X.; Ma, W.; Wei, X. Three new isochromans from the mycelial culture of a Cylindrocarpon fungus. Heterocycles 2006, 68, 1955-1959.

7. Xin, Z.H.; Li, T.; Zhu, T.J.; Wang, W.L.; Du, L.; Fang, Y.C.; Gu, Q.Q.; Zhu, W.M. Isocoumarin derivatives from the sea squirt-derived fungus Penicillium stoloniferum QY2-10 and the halotolerant fungus Penicillium notatum B-52. Arch. Pharm. Res. 2007, 30, 816-819.

8. Wakana, D.; Hosoe, T.; Itabashi, T.; Okada, K.; de Campos Takaki, G.M.; Yaguchi, T.; Fukushima, K.; Kawai, K.-I. New citrinin derivatives isolated from Penicillium citrinum. J. Nat. Med. 2006, 60, 279-284.

9. Clark, B.R.; Capon, R.J.; Lacey, E.; Tennant, S.; Gill, J.H. Citrinin revisited: From monomers to dimers and beyond. Org. Biomol. Chem. 2006, 4, 1520-1528.

10. Cameron, D.W.; Craik, J.C.A. Colouring matters of the aphididae. Part XXXVI. The configuration of the glucoside linkage in protoaphins. J. Chem. Soc. C 1968, doi:10.1039/J39680003068.

11. Sankawa, U.; Shimada, H.; Sato, T.; Kinoshita, T.; Yamasaki, K. Biosynthesis of scytalone. Chem. Pharm. Bull. 1981, 29, 3536-3542.

12. Yamamoto, K.; Hatano, H.; Arai, M.; Shiomi, K.; Tomoda, H.; Omura, S. Structure elucidation of new monordens produced by Humicola sp FO-2942. J. Antibiot. 2003, 56, 533-538.

13. Inacio, M.L.; Silva, G.H.; Teles, H.L.; Trevisan, H.C.; Cavalheiro, A.J.; Bolzani, V.D.S.; Young, M.C.M.; Pfenning, L.H.; Araujo, A.R. Antifungal metabolites from Colletotrichum gloeosporioides, an endophytic fungus in Cryptocarya mandioccana Nees (Lauraceae). Biochem. Syst. Ecol. 2006, $34,822-824$.

14. Kokubun, T.; Veitch, N.C.; Bridge, P.D.; Simmonds, M.S.J. Dihydroisocoumarins and a tetralone from Cytospora eucalypticola. Phytochemistry 2003, 62, 779-782.

15. Cimmino, A.; Villegas-Fernandez, A.M.; Andolfi, A.; Melck, D.; Rubiales, D.; Evidente, A. Botrytone, a new naphthalenone pentaketide produced by Botrytis fabae, the causal agent of chocolate spot disease on Vicia faba. J. Agric. Food Chem. 2011, 59, 9201-9206.

16. Machida, K.; Matsuoka, E.; Kasahara, T.; Kikuchi, M. Studies on the constituents of Juglans species. I. Structural determination of (4S)- and (4R)-4-hydroxy-alpha-tetralone derivatives from the fruit of Juglans mandshurica MAXIM. var. sieboldiana MAKINO. Chem. Pharm. Bull. 2005, 53, 934-937. 
17. Krohn, K.; Biele, C.; Drogies, K.H.; Steingrover, K.; Aust, H.J.; Draeger, S.; Schulz, B. Fusidilactones, a new group of polycyclic lactones from an endophyte, Fusidium sp. Eur. J. Org. Chem. 2002, 14, 2331-2336.

18. Yan, S.; Li, S.; Wu, W.; Zhao, F.; Bao, L.; Ding, R.; Gao, H.; Wen, H.A.; Song, F.; Liu, H.W. Terpenoid and phenolic metabolites from the fungus Xylaria sp associated with Termite Nests. Chem. Biodivers. 2011, 8, 1689-1700.

19. Lu, Z.Y.; Lin, Z.J.; Wang, W.L.; Du, L.; Zhu, T.J.; Fang, Y.C.; Gu, Q.Q.; Zhu, W.M. Citrinin dimers from the halotolerant fungus Penicillium citrinum B-57. J. Nat. Prod. 2008, 71, 543-546.

20. Gerwick, W.H.; Nagle, D.G.; Proteau, P.J. Oxylipins from marine-invertebrates. Top. Curr. Chem. 1993, 167, 117-180.

21. Orsini, F.; Pelizzoni, F.; Verotta, L.; Aburjai, T.; Rogers, C.B. Isolation, synthesis, and antiplatelet aggregation activity of resveratrol 3-O-beta-D-glucopyranoside and related compounds. $J$. Nat. Prod. 1997, 60, 1082-1087.

22. Pittayakhajonwut, P.; Suvannakad, R.; Thienhirun, S.; Prabpai, S.; Kongsaeree, P.; Tanticharoen, M. An anti-herpes simplex virus-type 1 agent from Xylaria mellisii (BCC 1005). Tetrahedron Lett. 2005, 46, 1341-1344.

23. Jimenez-Teja, D.; Daoubi, M.; Collado, I.G.; Hernandez-Galan, R. Lipase-catalyzed resolution of 5-acetoxy-1,2-dihydroxy-1,2,3,4-tetrahydronaphthalene. Application to the synthesis of $(+)-(3 R, 4 S)$-cis-4-hydroxy-6-deoxyscytalone, a metabolite isolated from Colletotrichum acutatum. Tetrahedron 2009, 65, 3392-3396.

24. Qian, P.Y.; Xu, Y.; Fusetani, N. Natural products as antifouling compounds: Recent progress and future perspectives. Biofouling 2010, 26, 223-234.

25. Halangk, W.; Lerch, M.M.; Brandt-Nedelev, B.; Roth, W.; Ruthenbuerger, M.; Reinheckel, T.; Domschke, W.; Lippert, H.; Peters, C.; Deussing, J. Role of cathepsin B in intracellular trypsinogen activation and the onset of acute pancreatitis. J. Clin. Invest. 2000, 106, 773-781.

26. Nimmesgern, E.; Black, J.; Futer, O.; Fulghum, J.R.; Chambers, S.P.; Brummel, C.L.; Raybuck, S.A.; Sintchak, M.D. Biochemical analysis of the modular enzyme inosine 5'-monophosphate dehydrogenase. Protein Expr. Purif. 1999, 17, 282-289.

27. Montalibet, J.; Skorey, K.I.; Kennedy, B.P. Protein tyrosine phosphatase: Enzymatic assays. Methods 2005, 35, 2-8.

28. Nakajima, K.; Powers, J.C.; Ashe, B.M.; Zimmerman, M. Mapping the extendedsubstrate binding-site of cathepsing and human-leukocyte elastase-Studies with peptide-substrates related to the alpha-1-protease inhibitor reactive site. J. Biol. Chem. 1979, 254, 4027-4032.

29. Qi, S.H.; Xu, Y.; Xiong, H.R.; Qian, P.Y.; Zhang, S. Antifouling and antibacterial compounds from a marine fungus Cladosporium sp F14. World J. Microbiol. Biotechnol. 2009, 25, 399-406.

(C) 2013 by the authors; licensee MDPI, Basel, Switzerland. This article is an open access article distributed under the terms and conditions of the Creative Commons Attribution license (http://creativecommons.org/licenses/by/3.0/). 